\title{
A Study of Age, Body Weight and Scrotal Circumference on Semen Production in Buck
}

\author{
CSS, BAIF, Urulikanchan, Pune 412202, India \\ *Corresponding author
}

Pradip D. Kadam*, Mohan R. Raut, Shivaji H. Sontakke and Jayant R. Khadase

\section{A B S T R A C T}

\begin{tabular}{|c|}
\hline Keywords \\
\hline $\begin{array}{l}\text { Buck, Semen, } \\
\text { Scrotal } \\
\text { circumference, } \\
\text { initial motility, } \\
\text { frozen straws, } \\
\text { concentration }\end{array}$ \\
\hline Article Info \\
\hline $\begin{array}{l}\text { Accepted: } \\
18 \text { May } 2020 \\
\text { Available Online: } \\
10 \text { June } 2020\end{array}$ \\
\hline
\end{tabular}

Keywords

Buck, Semen,

Scrotal

circumference, initial motility, frozen straws, concentration

Article Info

Available Online
The present study aimed to find out correlation of age, body weight and scrotal circumference with semen parameters in Beetle and Black Bengal Bucks. Total 12 buck selected 6 of each breed. Average Age was $24.00 \pm 0.00 \& 22.27 \pm 0.035$ months, body weight was $55.06 \pm 0.306 \& 42.47 \pm 0.200 \mathrm{~kg}$ and scrotal circumference was $27.35 \pm 0.57 \& 26.25 \pm 0.034 \mathrm{~cm}$ in Bettle and Osmanabadi bucks, respectively. Average Semen volume was $1.27 \pm 0.027 \& 1.30 \pm 0.030 \mathrm{ml}$, sperm concentration was $5601.63 \pm 75.810 \& 4964.56 \pm 100.075$ million, initial motility was $83.03 \pm 0.215 \& 82.65 \pm 0.352$ per cent, $59.45 \pm 0.283 \& 58.96 \pm 0.386$ per cent was the post thaw motility and $66.26 \pm 2.192 \& 59.45 \pm 2.692$ was the number of straw produced from single ejaculate in Bettle and Osmanadi Breed, Respectively. Age was positively correlates with the body weight, scrotal circumference and concentration in Osmanabadi bucks. Body weight was found positive relation in terms of scrotal circumference and concentration in Beetal but in Osmanabadi only with Age. Scrotal circumference was positively correlate with body weight, volume and concentration in case of all selected breeds.

\section{Introduction}

The worlds goat population is around 924 million and which is increasing at the rate of 2.34 per cent per annum (FAO, 2011).According to $19^{\text {th }}$ livestock census the Goat population in India is around 135.2 million. Goat is a most important species because short gestation period, higher rate of fecundity and the market demand of the goat products. Profitability of goat farming is mainly influenced by reproductive efficacy of a doe. Male fertility is directly depend on the normalcy of genital organ, age, body weight, nutrition, general health and endocrine balance (Peter, 2002).

Buck is considered as half of flock because they are responsible for conception rate and establishment of high genetic merit of the kid (Ford et al., 2009). Selection of buck for the breeding purpose is most important aspect because more attention required on body weight, growth rate and soundness of sex 
organ. Male Fertility is an important factor in caprine reproduction since numerous does are generally bred to a single buck. Hence, it is important to evaluate the male fertility prior to breeding (Kridli et al., 2005).

Higher concentration and volume of semen obtained when semen collected at regular interval twice a day or once day for a certain period which not affect the buck semen quality (Shamsuddin et al., 2000). There are limited references found on the relationship of Age, body weight and scrotal circumference on the semen quality and quantity in buck. Scrotal circumference and body are most decisive factor in breeding soundness examination of buck. Hence this study was undertaken to assess the effect of body weight and scrotal circumference on semen production in buck.

\section{Materials and Methods}

The present research trial was conducted at BAIF development research foundation at Goat semen station, Wagholi, district Pune during $1^{\text {st }}$ January 2019 to $28^{\text {th }}$ March 2019.

Total 12 bucks of two breeds were selected and out of that six of Beetal, six of Osmanabadi, bucks of different age groups and body weight were included in the trail. Before selection of the experimental bucks general body health were examined. Testes and scrotum were also examined to rule out any type of abnormality. All selected bucks were reared under intensive management system. Vaccination, deworming and dipping were done in all selected bucks as per MSP.

The body weights of all bucks were measured by using electronic weighing balance. Scrotal circumference was measured using flexible measuring tape in centimetre once in a three month (Akpa et al., 2006). Semen sample from all bucks were collected thrice a week on alternate day by artificial vagina method having $45^{\circ} \mathrm{C}$ temperature and 6 inch length. Semen samples were evaluated immediately after collection for colour, volume, initial motility and concentration. Volume of semen was measured using graduated semen collection tube in centimetres. Colour of each ejaculates was categorized as, milky, creamy, watery and bloody.

Concentration of all samples was measured with the help of photometer (IMV manufacture) by 1: 100 dilutions. Initial motility was determined by placing drop of diluted semen on pre warm glass slide and covered with cover slip and examined under the 20X magnification.

The samples were diluted by single dilution method and after 10 min packaging was carried out then produced straws were subjected for equilibration for four hours at $4 \mathrm{C}$. Freezing was undertaken by conventional method (static vapour pressure). Samples were subjected for post thaw motility $24 \mathrm{hrs}$ after the freezing. Frozen straw having motility more than 50 per cent were stored in wide mouth $\mathrm{LN}_{2}$ container according to breed and individual buck. The data were analysed with the help of statistical correlation.

\section{Results and Discussion}

Semen parameters in relation to Age, Body weight and scrotal circumference of all selected Goat breed are summarised in the following table no 1. In case of Beetal average Age was 24.00 \pm 0.00 months, body weight was $55.06 \pm 0.306 \mathrm{~kg}$ and scrotal circumference was $27.35 \pm 0.57 \mathrm{~cm}$.

The semen parameters of beetal breed in three month periods are as follows i.e. Average Semen volume was1.27 $\pm 0.027 \mathrm{ml}$, $5601.63 \pm 75.810$ million sperm concentration, initial motility was $83.03 \pm 0.215$ per cent, 
$59.45 \pm 0.283$ per cent was the post thaw motility and $66.26 \pm 2.192$ was the number of straw produced from single ejaculate.

Average age of four Osmanabadi breed was $22.27 \pm 0.035$ months, $42.47 \pm 0.200 \mathrm{~kg}$ was the average body weight and average scrotal circumference was $26.25 \pm 0.034 \mathrm{~cm}$.in semen parameters the average volume was $1.30 \pm 0.030 \mathrm{ml}, 4964.56 \pm 100.075$ million was the concentration, $82.65 \pm 0.352$ per cent initial motility, $58.96 \pm 0.386$ per cent post thaw motility and 59.45 \pm 2.692 was the number of straws produced per ejaculates in Osmanabadi buck. (Table no. 1).

In beetal breed, after statistical analysis we did not found correlation of Age with body weight, scrotal circumference and all other seminal parameters because the selected bucks were of same age. Body weight was positively correlated with scrotal circumference, concentration and frozen straws whereas, negatively correlate with volume, initial motility and post thaw motility. Scrotal circumference of beetal breed was found significant difference in terms of body weight, volume, concentration and frozen straws but non-significant difference with initial and post thaw motility (Table 2).

in case of Osmanabadi breed after statistical analysis we found significant difference of Age with body weight, Scrotal circumference, concentration and initial motility, but no significance with Volume, post thaw motility and number of frozen straws from single ejaculate whereas, body weight was positively correlate with only age but, negatively correlate with all other physical and seminal parameters. Scrotal circumference in beetal buck was found significant difference with Age, Volume and concentration but, nonsignificant difference with all others physical and seminal parameters (Table.3)
Chuck Okere et al., (2011) reported that BCS were positively correlated with body weight and scrotal circumference shows positive and moderate correlation with semen volume, which is similar with present finding in all bucks with scrotal circumference. The body weight and scrotal circumference of crossbred bulls influenced all semen production traits except the post thaw motility was not affected very much by the body weight of bulls (Gopinathan, 2016) finding in terms of post thaw motility with all parameters was positively correlated with present study of buck.

Semen production mostly depend upon age, sexual maturity, nutritional status, general health condition, endocrine mechanism and soundness of sexual organ and the season (Peter, 2002; Karagiannidis et al., 2000). Das et al., (2006) documented that the volume of semen ranges from $0.16-0.51 \mathrm{ml}$ in case of black Bengal buck, which is lower than that of the present study.

This difference might be due to above mentioned reason. Kabiraj et al., (2011) concluded that more the testicular circumference more the concentration of spermatozoa, this could be due to higher testicular size with higher spermatogenic activity this finding positively correlated with the present finding.

Shamsuddin et al., (2002) reported that the mean scrotal circumference of black Bengal breed at puberty ranged from 14.0 to $16.0 \mathrm{~cm}$, which is positively support the present finding. Testicular parameters and semen parameters were increased with advancement of age and body weight (Kabiraj, 2011). Raji et al., (2008) who reported a significant difference between testicular weight and body weight in indigenous goat of Nigeria. 
Table.1 Average value of Age, body weight, scrotal circumference and semen parameters in Beetal and Osmanabadi bucks

\begin{tabular}{|c|c|c|c|c|c|c|c|c|}
\hline $\begin{array}{l}\text { Breed } \\
\text { Rarameters }\end{array}$ & $\begin{array}{c}\text { Age } \\
\text { (month) } \\
\pm \mathrm{SE}\end{array}$ & $\begin{array}{l}\text { BWT } \\
\pm \text { SE }\end{array}$ & $\begin{array}{c}\text { Scrotal } \\
\text { circum } \\
\text { ference } \\
\pm \mathrm{SE}\end{array}$ & $\begin{array}{c}\text { Volume } \\
\pm \mathrm{SE}\end{array}$ & $\begin{array}{c}\text { Concentration } \\
\pm S E\end{array}$ & $\begin{array}{c}\text { Initial } \\
\text { motility } \\
\pm \mathrm{SE}\end{array}$ & $\begin{array}{l}\text { Post thaw } \\
\text { motility } \\
\pm \mathrm{SE}\end{array}$ & $\begin{array}{c}\text { Frozen } \\
\text { straws } \\
\pm \text { SE }\end{array}$ \\
\hline Beetal & $\begin{array}{c}24.00 \pm \\
0.00(6)\end{array}$ & $\begin{array}{c}55.06 \pm \\
0.306 \\
(6)\end{array}$ & $\begin{array}{c}27.35 \\
\pm 0.57 \\
(6)\end{array}$ & $\begin{array}{c}1.27 \\
\pm 0.027 \\
(282)\end{array}$ & $\begin{array}{c}5601.63 \\
\pm 75.810 \\
(282)\end{array}$ & $\begin{array}{c}83.03 \\
\pm 0.215 \\
(282)\end{array}$ & $\begin{array}{c}59.45 \\
\pm 0.283 \\
(282)\end{array}$ & $\begin{array}{c}66.26 \\
\pm 2.192 \\
(282)\end{array}$ \\
\hline Osmanabadi & $\begin{array}{c}22.27 \pm \\
0.035(6)\end{array}$ & $\begin{array}{c}42.47 \pm \\
0.200 \\
(6)\end{array}$ & $\begin{array}{c}26.25 \pm \\
0.034 \\
(6)\end{array}$ & $\begin{array}{l}1.30 \pm \\
0.030 \\
(164)\end{array}$ & $\begin{array}{c}4964.56 \\
\pm 100.075 \\
(164)\end{array}$ & $\begin{array}{c}82.65 \pm \\
0.352 \\
(164)\end{array}$ & $\begin{array}{c}58.96 \pm \\
0.386 \\
(164)\end{array}$ & $\begin{array}{c}59.45 \pm \\
2.692 \\
(164)\end{array}$ \\
\hline
\end{tabular}

Table.2 Correlation of Body weight and scrotal circumference with various semen parameters in Beetal bucks

\begin{tabular}{|c|c|c|c|c|c|c|c|c|}
\hline Parameters & Age & $\begin{array}{c}\text { Body } \\
\text { weight }\end{array}$ & $\begin{array}{c}\text { Scrotal } \\
\text { circumference }\end{array}$ & Volume & Concentration & $\begin{array}{c}\text { Initial } \\
\text { motility }\end{array}$ & $\begin{array}{c}\text { Post thaw } \\
\text { motility }\end{array}$ & $\begin{array}{c}\text { Frozen } \\
\text { Straws }\end{array}$ \\
\hline Age & --- & --- & --- & --- & --- & --- & --- & --- \\
\hline & & & 0.2040 & 0.0624 & 0.3016 & 0.0414 & 0.0344 & 0.1385 \\
Body weight & --- & --- & 0.0006 & 0.2963 & 0.0001 & 0.4889 & 0.5655 & 0.0200 \\
& & & $(\mathrm{~S})$ & $(\mathrm{NS})$ & $(\mathrm{S})$ & $(\mathrm{NS})$ & $(\mathrm{NS})$ & $(\mathrm{S})$ \\
\hline Scrotal & & 0.2040 & & 0.3987 & 0.1994 & 0.1033 & 0.0009 & 0.3525 \\
circumference & & 0.0006 & --- & 0.0001 & 0.0008 & 0.0833 & 0.9882 & 0.0001 \\
& & $(\mathrm{~S})$ & & $(\mathrm{S})$ & $(\mathrm{S})$ & $(\mathrm{NS})$ & $(\mathrm{NS})$ & $(\mathrm{S})$ \\
\hline
\end{tabular}

Table.3 Correlation of Body weight and scrotal circumference with various semen parameters in Osmanabadi bucks

\begin{tabular}{|c|c|c|c|c|c|c|c|c|}
\hline Parameters & Age & $\begin{array}{c}\text { Body } \\
\text { weight }\end{array}$ & $\begin{array}{c}\text { Scrotal } \\
\text { circumference }\end{array}$ & Volume & Concentration & $\begin{array}{c}\text { Initial } \\
\text { motility }\end{array}$ & $\begin{array}{c}\text { Post thaw } \\
\text { motility }\end{array}$ & $\begin{array}{c}\text { Frozen } \\
\text { Straws }\end{array}$ \\
\hline Age & --- & 0.8214 & 0.3496 & 0.0678 & 0.2883 & 0.1581 & 0.0576 & -0.1129 \\
& & 0.0001 & 0.0001 & 0.3882 & 0.0002 & 0.0431 & 0.4636 & 0.1501 \\
& & $(\mathrm{~S})$ & $(\mathrm{S})$ & $(\mathrm{NS})$ & $(\mathrm{S})$ & $(\mathrm{S})$ & $(\mathrm{NS})$ & $(\mathrm{NS})$ \\
\hline Body weight & 0.8214 & --- & 0.1197 & 0.0704 & 0.1469 & 0.1170 & 0.0655 & 0.1342 \\
& 0.0001 & & 0.1267 & 0.3703 & 0.0605 & 0.1359 & 0.4049 & 0.0867 \\
& $(\mathrm{~S})$ & & $(\mathrm{NS})$ & $(\mathrm{NS})$ & $(\mathrm{NS})$ & $(\mathrm{NS})$ & $(\mathrm{NS})$ & $(\mathrm{NS})$ \\
\hline Scrotal & 0.3496 & 0.1197 & & 0.2030 & 0.2466 & 0.0352 & 0.6545 & 0.0047 \\
circumference & 0.0001 & 0.1267 & --- & 0.0091 & 0.0015 & 0.6545 & 0.3167 & 0.9522 \\
& $(\mathrm{~S})$ & $(\mathrm{NS})$ & & $(\mathrm{S})$ & $(\mathrm{S})$ & $(\mathrm{NS})$ & $(\mathrm{NS})$ & $(\mathrm{NS})$ \\
\hline
\end{tabular}

Aliya et al., (2016) revealed that body weight and scrotal circumference was positively correlated with semen parameters like semen colour, semen concentration, semen motility, and live and dead percentage, which is supporting the present findings in terms of semen concentration and initial motility. A satisfactory potential breeding buck should 
have suitable scrotal circumference because scrotal circumference positively correlates with sperm concentration and total spermatozoa per ejaculates (Bongso, 1982).

\section{References}

Aliyu, A. M., Ram Pal, S., Nasir, M and Umar, A. S. 2016. A study of Semen Characteristics As Influenced by Body Weight and Scrotal Circumference in Red Sokoto Bucks. IOSR Journal of Agriculture and Veterinary Science. 9:48-51.

Apka, G. N., Suleiman I. O., Alphonsus, C.2006. Relationship between body and scrotal measurements and semen characteristics in Yankasa Ram. Continental Journal of Animal and Veterinary Research (16): 78.

Bongso, T. A., Jainudeen, M. R., Zahrah, A. S. 1982. Relationship of scrotal circumference to age, body weight and onset of spermatogenesis in goats. Theriogenology. 18: $513-524$

Chuck Okere., Patrica Bradley., E. Rick Bridges., Olga Bolden-Tiller., Durandal Ford and Anthony Paden. 2011. Relationship among Body confirmation, Testicular traits and Semen Output in Electro- ejaculate Pubertal Kiko Goat Bucks. ARPN Journal of Agricultural and Biological Science., 6: 8

Das, S. K., Husain, S. S., Amin, M. R., Munim, T., Hoque M. A., khandoker, MAMY 2000. Growth performance of progeny using selected Black Bengal bucks. Bangladesh J. Anim. Sci., 35: 27-35

FAOSTAT, United Nations Food and Agriculture Organization 2011

Ford, D., Okere, C., and Bolden, O. 2009. Libido test scores, Body confirmation and testicular traits in Boar and Kiko Goats Bucks. Journal of Agricultural and
Biological Sciences. $4(5): 1-8$ Gopinathan, A., Sivaselvam, S. N., Karthickeyan, S. M. K. and Kulasekar K. 2016. Effect of Body weight and Scrotal circumference on semen production traits in Crossbred Holstein Friesian Bull. Indain Journal of Animal Reproduction 39(1): 24-27

Karagiannidis, A., varsakeli, S., Karatzas, G. 2000. Characteristics and seasonal variations in the semen of Alpine, Saanen ans Damascus goat bucks born and raised in Greece. Theriogen, 53: 1285- 1293.

Kridli, R. T., Tabaa, M. J., Sawalha, R. M., Amashe, M. J. 2005. Comparative study of Scrotal circumference and semen characteristics of mountain Black Goat and its crossbred with Damascus Goat as affected by different factors. Jordan Journal of Agricultural Science. $1(1)$ : 3740.

Peters, K. J. 2002. Evaluation of goat populations in tropical and Subtropical environments. http//kinne.net/fertbuck. html.

Raji, A. O., Lgwebuike, J. U., Aliyu, J 2008. Testicular biometry and its relationship with body weight of indigenous goat in a semi arid region of Nigeria. ARPN J. Agric. Bio. Sci., 3(4): 35-38

Sanjoy Kumar Kabiraj, Masudul Hoque, S. A., Yahia khandoker, M. A. M. and Syed Sakhawat Husain. 2011.Testicular biometry and its relationship with body weight and semen output of black Bengal Bucks in Banglasdesh. Journal of Cell and Animal Biology. 5(2): 27-32

Shamsuddin, M., Amiri Y., Bhuiyan M. M.U. 2000. Characteristics of buck semen with regards to ejaculate numbers, collection intervals, dilution and preservation periods. Reproduction. Dom. $\quad$ Animals., 35:5357.

\section{How to cite this article:}

Pradip D. Kadam, Mohan R. Raut, Shivaji H. Sontakke and Jayant R. Khadase. 2020. A Study of Age, Body Weight and Scrotal Circumference on Semen Production in Buck. Int.J.Curr.Microbiol.App.Sci. 9(06): 1284-1288. doi: https://doi.org/10.20546/ijcmas.2020.906.159 